\title{
A Parallel Multigrid Solver for High Frequency Electromagnetic Field Analyses with Small-scale PC Cluster
}

\author{
Kuniaki Yosui Non-member（Murata Manufacturing co., ltd., yosui@murata.co.jp) \\ Takeshi Iwashita Member (Academic center for computing and media studies, Kyoto University) \\ Michiya Mori Non-member (Murata Manufacturing co., ltd.) \\ Eiichi Kobayashi Non-member (Murata Manufacturing co., ltd.)
}

Keywords: high frequency electromagnetic field analysis, finite element method, multigrid method, parallel computing, block Gauss-Seidel, block multicolor ordering

Finite element analyses of electromagnetic field are commonly used for designing of various electronic devices. The scale of the analyses becomes larger and larger, therefore, a fast linear solver is needed to solve linear equations arising from the finite element method. Since a multigrid solver is the fastest linear solver for these problems, parallelization of a multigrid solver is a quite useful approach. From the viewpoint of industrial applications, an effective usage of a small-scale PC cluster is important due to initial cost for introducing parallel computers. In this paper, a distributed parallel multigrid solver for a small-scale PC cluster is developed.

In high frequency electromagnetic field analyses, a special block Gauss-Seidel method based on node patches is used as a smoother for the multigrid solver instead of general smoothers such as GaussSeidel method or Jacobi method in order to improve a convergence rate. The node patch is given by a set of edge elements which share the same node, as shown in Fig. 1. The parallelization of the

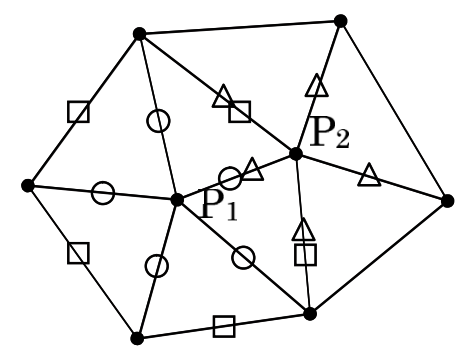

Fig. 1. Node patches

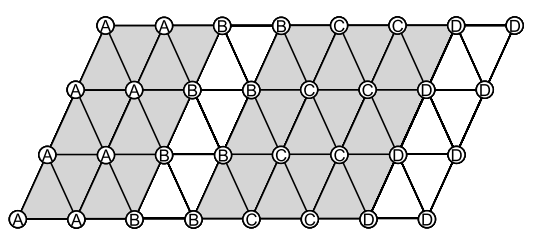

Fig. 2. Block multicolor ordering smoother is important to obtain high parallel efficiency for the multigrid solver, because the cost of the smoother is enormous in both the computational time and memory usage.

In order to parallelize the smoother, the block multicolor ordering technique is applied as follows. At first, all patches are split into some blocks labeled by colors in such a way that adjacent blocks are labeled by different colors with each other, as shown in Fig. 2. Next then, the blocks in the same color can be processed in parallel.

Numerical results are shown in Fig. 3 and Fig. 4. A 3.7-fold speed-up in computational time and 3.0-fold increase in the scale of the analysis were attained when the number of CPU is increased from one to five.

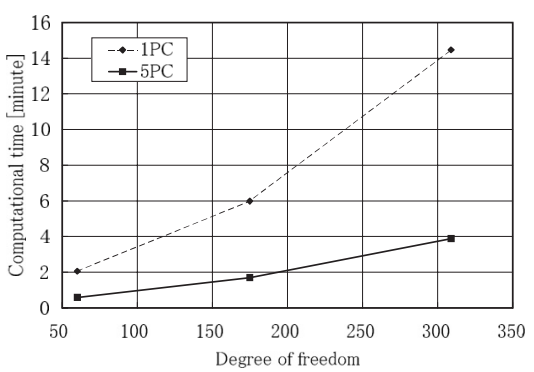

Fig. 3. Computational time of the multigrid solver

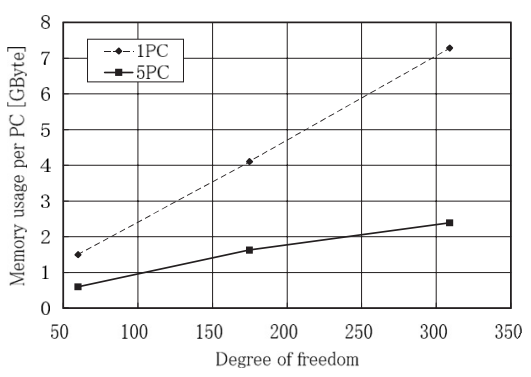

Fig. 4. Memory usage of the multigrid solver 


\title{
小規模 PCクラスタによる高周波電磁界解析のための 並列マルチグリッドソルバ
}

\author{
非会員 用水 邦明* 正 員 岩下 武史** \\ 非会員 森 倫也* 非会員 小林 英一*
}

\section{A Parallel Multigrid Solver for High Frequency Electromagnetic Field Analyses with Small-scale PC Cluster}

\author{
Kuniaki Yosui*, Non-member, Takeshi Iwashita**, Member, Michiya Mori*, Non-member,
}

Eiichi Kobayashi*, Non-member

Finite element analyses of electromagnetic field are commonly used for designing of various electronic devices. The scale of the analyses becomes larger and larger, therefore, a fast linear solver is needed to solve linear equations arising from the finite element method. Since a multigrid solver is the fastest linear solver for these problems, parallelization of a multigrid solver is a quite useful approach. From the viewpoint of industrial applications, an effective usage of a small-scale PC cluster is important due to initial cost for introducing parallel computers.

In this paper, a distributed parallel multigrid solver for a small-scale PC cluster is developed. In high frequency electromagnetic field analyses, a special block Gauss-Seidel smoother is used for the multigrid solver instead of general smoothers such as Gauss-Seidel smoother or Jacobi smoother in order to improve a convergence rate. The block multicolor ordering technique is applied to parallelize the smoother. A numerical exsample shows that a 3.7-fold speed-up in computational time and a 3.0-fold increase in the scale of the analysis were attained when the number of CPU was increased from one to five.

キーワード : 高周波電磁界解析, 有限要素法, マルチグリッド法, 並列処理, ブロックガウスザイデル, ブロック化多色順序付け

Keywords: high frequency electromagnetic field analysis, finite element method, multigrid method, parallel computing, block Gauss-Seidel, block multicolor ordering

\section{1. はじめに}

現在，電子部品の設計には電磁界解析手法が広く用いら れており，その主要な解析手法の一つとして有限要素法が ある。著者らが対象とする高周波電磁界解析では，解くべ き問題は最終的に辺要素に割り当てられた電界を未知数と する連立一次方程式に帰着する。最近では電子部品の小型 化・多機能化に伴い電子部品の構造が複雑化する傾向にあ り，精細なモデル作成のために多くの要素を用いる必要が ある。その結果，解くべき連立一次方程式の次元数が大き くなり，これを解くために長い計算時間と大容量の主記憶

\footnotetext{
* (株) 村田製作所

干 617-8555 長岡京市東神足 1-10-1

Murata Manufacturing Co., Ltd.

1-10-1, Higashikotari, Nagaokakyo 617-8555

**京都大学学術情報メディアセンター

干 606-8501 京都市左京区吉田本町

Academic Center for Computing and Media Studies, Kyoto University

Yoshidahonmachi, Sakyo-ku, Kyoto 606-8501
}

装置（メモリ）が必要となってきている。最近では，こう した問題に対してマルチグリッド法(1)(2) の有効性が明らか になり，解析速度や解析規模の向上に大きく寄与してきた。 しかし，マルチグリッド法を用いた場合においても，高周波 電磁界解析では，最も粗なグリッドの密度が対象とする電 磁界の波長と比べて十分に細かいことが要求されるため, 最 も粗なグリッド上で一般的に使用される直接法ソルバが計 算時間とメモリ容量の両面において解析全体のボトルネッ クとなっていた。そこで, 著者らはまず当該の直接法ソル バを反復法ソルバに置き換えることを試みた。その結果, 特殊な前処理手法を適用することにより反復法による求解 が可能であることを示し，メモリ容量の削減に成功した ${ }^{(3)}$ 。 しかし，計算時間の比較の点においては，当該の研究にお いて直接法ソルバと比べて優位な結果は得られなかった。

そこでこのような背景の下, 本研究ではマルチグリッド 法による求解処理を並列化し, 計算時間の短縮を行うことを 試みる。近年の学術分野では $1000 \mathrm{CPU}$ を超えるスーパー コンピュータが利用可能になってきているが，産業応用の 
観点からは, 導入コストの小さい 4 から $8 \mathrm{CPU}$ の小規模 $\mathrm{PC}$ クラスタの効果的な利用が重要である。そこで，本論文で は小規模な PC クラスタを対象とした高周波電磁界解析の 並列処理による高速化について研究する。現在, 高周波電磁 界の辺要素有限要素法をマルチグリッド法で解く場合, 安定 した収束解を得るためにマルチグリッド法のスムーザとし て, Hybrid smoother ${ }^{(4)(5)}$ や Arnold らの特殊なブロックガウ スザイデル法 ${ }^{(5)(6)}$ を用いる必要があることが知られている。 マルチグリッド法による求解処理において，スムーザが占 める計算コストは大きいためその並列化は重要である。そ こで本研究では, Arnoldらの手法を対象とし，その並列処 理方法として, 通常の節点有限要素法や差分法で用いられる 多色順序付け法，ブロック化多色順序付け法 (7) を応用する 方法を提案する。また，最も粗なグリッド上での線形ソル バとして, 並列化された直接法ソルバである MUMPS ${ }^{(8) \sim(10)}$ を導入する。関連する研究としては, 文献(11) が著者らと 独立に行われており，こちらは代数マルチグリッド法によ る低周波電磁界解析を対象としている。本論文では，並列 処理方法についての詳細を述べ，その有効性について数值 実験により検証を行う。

\section{2. 高周波電磁界に対する有限要素法}

電界を未知数とする定式化を行うために，基本方程式と しては (1)，(2) 式に示すべクトル波動方程式を用いる。た だし， $\mu$ は透磁率， $\epsilon$ は誘電率， $\sigma$ は導電率， $\omega$ は角周波数 である。

$$
\begin{aligned}
& \nabla \times \mu^{-1} \nabla \times E-\omega^{2} \tilde{\epsilon} E=0 \\
& \tilde{\epsilon}=\epsilon+(j \omega)^{-1} \sigma \cdots \cdots
\end{aligned}
$$

(1) 式の弱形式を離散化することで離散化方程式 (3)〜 (6) を

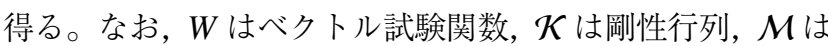
質量行列である。

$$
\begin{aligned}
& A x_{E}=b_{E} \\
& A=\mathcal{K}-\omega^{2} \mathcal{M} \\
& \mathcal{K}_{i, j}=\sum_{e} \int_{e} \mu^{-1}\left(\nabla \times W_{i}\right) \cdot\left(\nabla \times W_{j}\right) d v \\
& \mathcal{M}_{i, j}=\sum_{e} \int_{e} \tilde{\epsilon} W_{i} \cdot W_{j} d v
\end{aligned}
$$

(3) 式について, 解ベクトル $x_{E}$ は領域内部の電界に相当す る。また，右辺べクトル $b_{E}$ はポート部の電界モードから算 出されるべクトルである。すなわち，(3) 式を解くことは, ポート部に電界モードを与え領域内部の電界を求めること を意味する。

\section{3. マルチグリッドソルバ}

マルチグリッド法は微分方程式を有限要素法や差分法で 離散化して得られる連立一次方程式に対する反復解法とし て，近年注目されている手法である。マルチグリッド法は， 離散化の密度の異なる複数のグリッド（有限要素法の場合
は有限要素メッシュ）を用いることを特徴とする。密なグ リッドでは誤差の空間的高周波成分，粗なグリッドでは誤 差の低周波成分を除去し，全体として誤差の全ての周波数 成分をまとめて効率よく除去することができる。各グリッ ドにおける誤差の除去処理のことをスムージング，そのた めの手法をスムーザと呼ぶ。スムーザとしては，ヤコビ法 やガウスザイデル法などを使用するのが一般的である。ま た，最も粗なグリッドに対しては，通常は直接法が用いら れる。マルチグリッド法は単体で反復法として用いること も可能だが，共役勾配法をはじめとする非定常反復法（ク リロフ部分空間法）の前処理として用いることで，より速 く確実に収束解を得られるようになる。本研究でもマルチ グリッド法をクリロフ部分空間法のひとつである対称擬似 最小残差法 (SQMR 法) ${ }^{(12)}$ の前処理として用いる方法を採 用しており，本論文では以下，この方法を単に「マルチグ リッドソルバ」と表記することとする。

〈3・1〉 NP-BGS スムーザ＼cjkstart通常の節点有限要素法の 場合，マルチグリッド法のスムーザとしてはヤコビ法やガ ウスザイデル法などを用いるのが一般的であるが, 辺要素 を用いた高周波電磁界有限要素解析においては, 十分な収束 性が得られない。収束性を改善するためのスムーザとして, Hiptmair らの Hybrid smoother と Arnold らが提案したス ムーザ (本論文では NP-BGS スムーザと呼ぶ) がある。本研 究では後者を採用している。NP-BGS スムーザは, ブロック ガウスザイデル法において電磁界有限要素解析に有効な特 殊なブロック構成を用いる方法である。ここでは NP-BGS スムーザのアルゴリズムについて簡単に説明する。詳細に ついては文献(3) で述べられている。

NP-BGS スムーザでは，まず有限要素メッシュにおいて 節点パッチを作成する。ここで，節点パッチとは，ある節 点についてそれを端点とする辺要素の集合である。Fig. 1 に節点パッチの例を示す。ここでは，○印のついた辺要素 の集合が節点パッチ $P_{1}, \triangle$ 印のついた辺要素の集合が節点 パッチ $P_{2}$ となる。節点パッチを作成した後に, Fig. 2 に示 す手順を行うことでスムージング操作が行われる。Fig. 2 において, $A_{i}$ は連立一次方程式 $A x=b$ の係数行列 $A$ のう ち節点パッチ $P_{i}$ に関連した部分よりなる $n_{i} \times n_{i}$ 行列を表 す。ここで $n_{i}$ は $P_{i}$ 内に含まれる辺要素の数である。Fig. 1 の例では $n_{1}=5, n_{2}=5$ である。また, 演算子 $R_{i}$ は, 辺要 素全体の集合から節点パッチ $P_{i}$ に含まれる辺要素だけを

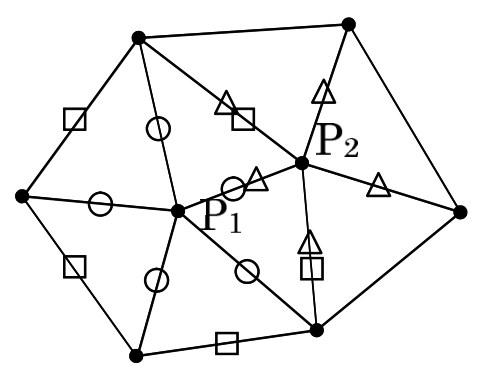

Fig. 1. Node patches. 


$$
\begin{aligned}
& \text { Input: } x \text {; Output: } x_{n e w}=n p b g s(x) \\
& \text { for } \quad i=1,2, \ldots, p \\
& \qquad x_{\text {new }}=x+R_{i}^{T} A_{i}^{-1} R_{i}(b-A x)
\end{aligned}
$$

endfor

Fig. 2. NP-BGS smoother.

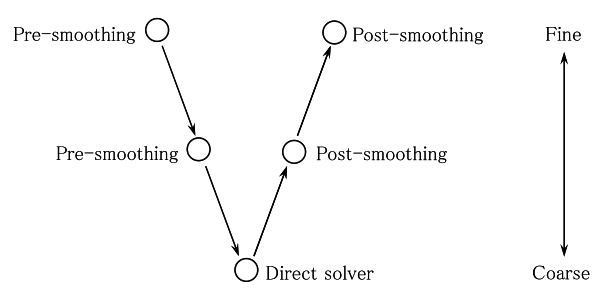

Fig. 3. V-cycle multigrid.

抽出し圧縮する操作を表す。よって，右辺括弧内の残差計 算 $(b-A x)$ は全ての行について計算する必要は無く, 節点 パッチ $P_{i}$ に含まれる辺要素に対応する行のみ計算すればよ い。この時，ベクトル $x$ については，節点パッチに含まれ る辺要素と，それを囲む位置にある辺要素に対応する行の 值が参照される。Fig. 2 では節点パッチ $P_{1}$ に含まれる辺要 素を○印，それを囲む辺要素を口印で表している。このう ち值が更新されるのは，○印のついた範囲となる。

Fig. 2 の処理は，各節点パッチ毎に局所的に有限要素法 を適用し得られる連立一次方程式 $A_{i} x_{i}=b_{i}$ を直接法で解く ことを意味している。

マルチグリッドソルバでは V-cycle マルチグリッド法 (Fig. 3 参照, 詳細は文献 (1) 参照) を使用する。V-cycle マ ルチグリッド法を SQMR 法などの対称係数行列用の反復 法の前処理として用いる場合には，プリスムージングとポ ストスムージングに抒ける節点パッチの処理順序を互いに 逆にする必要がある。つまり，プリスムージングにおいて Fig. 2 に従って操作を行った場合，ポストスムージングに おいては Fig. 2 中の for ループ部分を $p$ から 1 まで逆順に 行う。こうすることにより前処理行列が対称化され，マル チグリッド法を SQMR 法の前処理として用いることが可 能となる。

\section{NP-BGS スムーザの並列化}

後述の数值計算結果が示すように，マルチグリッドソル バにおいて，スムーザの計算コスト（計算時間とメモリ使 用量）が全体に占める割合は大きいため，その並列化は重 要である。本論文では, 多色順序付け法及びブロック化多 色順序付け法を応用した NP-BGS スムーザの並列化手法を 提案する。多色順序付け法とブロック化多色順序付け法に ついて説明した後，それらの NP-BGS スムーザへの適用方 法について述べる。 $\langle\mathbf{4} \cdot \mathbf{1}\rangle$ 多色順序付け法多色順序付け法は, ガウス ザイデル法や不完全 LU 分解法の代表的な並列化手法のひ とつとして知られている。例として次の 4 元連立一次方程 式を考える。

$$
\left(\begin{array}{cccc}
a_{11} & 0 & 0 & a_{14} \\
a_{21} & a_{22} & 0 & 0 \\
0 & a_{32} & a_{33} & 0 \\
0 & 0 & a_{43} & a_{44}
\end{array}\right)\left(\begin{array}{c}
x_{1} \\
x_{2} \\
x_{3} \\
x_{4}
\end{array}\right)=\left(\begin{array}{l}
b_{1} \\
b_{2} \\
b_{3} \\
b_{4}
\end{array}\right)
$$

連立一次方程式 (7) に対するガウスザイデル法の計算式は, 次のようになる。

$$
\begin{aligned}
& x_{1} \leftarrow a_{11}^{-1}\left(b_{1}-a_{11} x_{1}-a_{14} x_{4}\right) \\
& x_{2} \leftarrow a_{22}^{-1}\left(b_{2}-a_{21} x_{1}-a_{22} x_{2}\right) \\
& x_{3} \leftarrow a_{33}^{-1}\left(b_{3}-a_{32} x_{2}-a_{33} x_{3}\right) \\
& x_{4} \leftarrow a_{44}^{-1}\left(b_{4}-a_{43} x_{3}-a_{44} x_{4}\right)
\end{aligned}
$$

ガウスザイデル法ではこれらの式を例えば(8), (9), (10), (11) 式の順に計算していく。その際, 更新された $x_{i}(i=1,2,3,4)$ の值は, 以後の計算に即反映される。ここで (8) 式と (10) 式だけに着目すると, これらの 2 式に現れているすべての 変数が異なっており, 互いに干渉しないため, 並列処理の 観点からは独立と見なすことができる。同様のことが (9) 式と (11) 式についても当てはまる。多色順序付け法は, こ のような互いに干渉しない行を探し，それらを並列処理す る方法である。そのとき，互いに干渉しない行の集合を表 すために，「色」という表現が用いられる。本節の例では, (8) 式と (10) 式には A という「色」を，(9) 式と (11) 式に は B という「色」をつける。まず色 A を計算し，次に色 B を計算する。1つの色を計算している間は並列処理を行い, その色の計算が終わったところで同期をとり，次の色に進 む。よってガウスザイデル法の 1 反復の間に, 使用する色 の数と同じ回数の同期が必要となる。多色順序付け法によ り並列化されたガウスザイデル法の結果は，(10) 式の (9) 式への依存関係，および (8) 式の (11) 式への依存関係を無 視することになるため, 元のガウスザイデル法に対して反 復法としての解の収束性が変化する。

〈4·2〉 NP-BGS スムーザに対する多色順序付け法 通常のガウスザイデル法の計算は係数行列の行を単位と して行われるため, 多色順序付け法では行毎に色付けを行っ た。一方, 〈3・1〉節で述べたように, NP-BGS スムーザの計 算は節点パッチを単位として行われる。そのため, NP-BGS 法スムーザに対する多色順序付け法では, 節点パッチ毎に 色付けを行う。但し, 互いに干渉しない節点パッチを探し, それらを並列処理するという基本的な考方方は変わらない。

多色順序付け法の例を Fig. 4 に示す。〈3・1 節で述べた ように, NP-BGS スムーザにおいてある節点パッチを処理 するときに参照される未知数の範囲（以下，単に参照範囲 と記す）は，節点パッチを構成する各辺と，それを囲む辺 
との和集合となる。Fig. 4 では, 節点パッチ a と c の参照 範囲には色をつけて示し，節点パッチ $\mathrm{b}$ と $\mathrm{d}$ の参照範囲は 太線で示している。この場合， a と b, c と d は互いに干渉 しているため異なる色を付ける必要があるが，a と c，a と $\mathrm{d}, \mathrm{b}$ と $\mathrm{c}, \mathrm{b}$ と $\mathrm{d}$ は互いに干涉していないので, 同じ色をつ けることが可能である。そこで，例えば $\mathrm{a}$ と $\mathrm{c}, \mathrm{b}$ と $\mathrm{d}$ にそ れぞれ同じ色をつける。同様にして残りの節点パッチにも 色を付けていくことにより，NP-BGS スムーザの多色順序 付け法による並列化が可能となる。以下, 多色順序付け法 によって並列化した NP-BGS スムーザを MC-NP-BGS と 表記する。

〈4·3 ブロック化多色順序付け法 実際の 3 次元有限 要素解析で用いられるメッシュのほとんどは, 歪な四面体 要素が複雑に絡み合った形状をしており, 各々の節点パッ チはその周囲の多数の節点パッチと干渉している場合が多 い。そのような場合には多色順序付け法の色数を多くとる 必要があるが，多色順序付け法のアルゴリズムでは色数と 同じ回数の同期処理が必要であり，同期回数の増加は並列 処理の効率を悪化させるため, 並列処理の観点からは色数 を少なく抑えることが望まれる。そのための方策のひとつ として，ブロック化多色順序付け法が考えられる。ブロッ ク化多色順序付け法は，近接する節点パッチによるブロッ クを構成し，ブロック単位で色付けを行う。ブロック化多 色順序付け法の例を Fig. 5 に示す。Fig. 5 では, 節点パッ チをブロック化し A， B，C，D４４つのブロックを構成し ている。また，ブロック $\mathrm{A}$ とブロック $\mathrm{C}$ の参照範囲に色を つけて示している。ブロック A とブロック C は，互いに 干渉しないので，同じ色を付け並列処理することができる。 同様にして，ブロック B とブロック D も並列処理が可能で ある。各ブロック内については逐次的な NP-BGS スムーザ による処理を行う。節点パッチのブロック化方法としては は様々な方針が考えられるが，本論文では Fig. 5 のように メッシュを物理的にスライスするブロック化を行っている。 この方法ではほとんどの場合，2色のみで色付けすること ができる。以下，ブロック化多色順序付け法によって並列

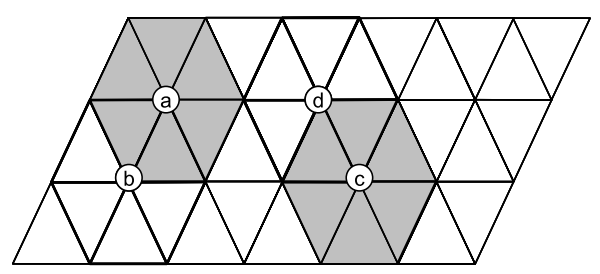

Fig. 4. Multicolor ordering.

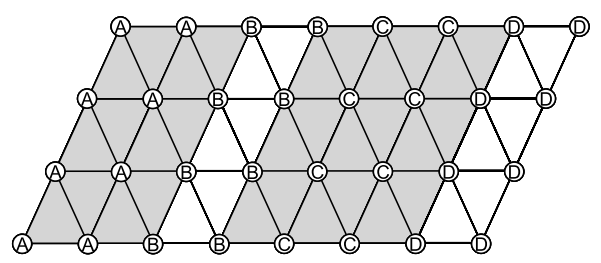

Fig. 5. Block multicolor ordering.
化した NP-BGS スムーザを BMC-NP-BGS と表記する。

\section{5. 数值実験}

〈5・1〉 評価用モデルと計算機 本論文では, マルチグ リッドソルバの性能評価用の解析モデルとして, Fig. 6 に 示すスパイラルインダクタを用いた。本モデルでは導体や 誘電体の損失を考慮している，即ち，(2) 式に抒いて導電 率 $\sigma$ は有限の值を持ち, 誘電率 $\epsilon$ は複素数となる。そのた め, 連立一次方程式の係数行列 - 右辺ベクトル・解ベクト ルはすべて複素数となっている。マルチグリッドソルバの グリッド数は 4 とした。使用モデルの各グリッドの自由度 を Table 1 に示す。計算には 5 ノードの PC クラスタを使 用した。その構成は Table 2 に示す。

$\langle\mathbf{5 \cdot 2 \rangle}$ マ マルチグリッドソルバの計算時間とメモリ使用 量はじめに予備実験として，マルチグリッドソルバの 計算を逐次処理で行い，計算時間とメモリ使用量を測定し た。これらの内訳を示すとそれぞれ Fig. 7 と Fig. 8 のとお りになった。これらの図から明らかなように，計算時間と メモリ使用量のほとんどはスムーザと最も粗なグリッドに 対する直接法ソルバによる LU 分解が占めており，マルチ グリッドソルバの並列化に扔いては，スムーザと直接法ソ ルバを高効率で並列化することが重要であることが判る。

$\langle\mathbf{5} \cdot \mathbf{3}\rangle$ スムーザの比較＼cjkstart並列マルチグリッドソルバで 用いるスムーザを決定するため，第４章で述べた NP-BGS スムーザの並列化手法を比較する。比較項目は，マルチグ リッドソルバの収束性, 並列度, 計算時間の 3 つである。 詳細は以下の小節で述べるが，まとめると Table 3 のとお りになる。どちらも一長一短であるが，対象としている小

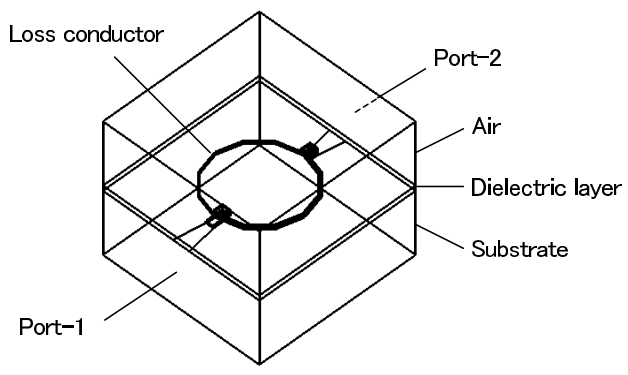

Fig. 6. A spiral inductor.

Table 1. Degrees of freedom.

\begin{tabular}{c|r}
\hline grid level & degrees of freedom \\
\hline \hline 1 & $3,088,742$ \\
\hline 2 & $1,341,995$ \\
\hline 3 & 641,723 \\
\hline 4 & 281,418 \\
\hline
\end{tabular}

Table 2. PC cluster.

\begin{tabular}{c|c}
\hline CPU & Intel@Xeon $₫ 3.6 \mathrm{GHz}$ \\
\hline Memory & $4 \mathrm{~GB}$ \\
\hline OS & SUSE Linux 9.1 \\
\hline Compiler & Intel $₫$ Fortran Compiler 9.1 \\
\hline MPI & MPICH-1.2.7 \\
\hline
\end{tabular}




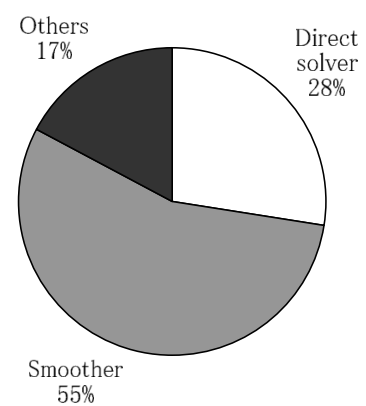

Fig. 7. A breakdown of computational time.

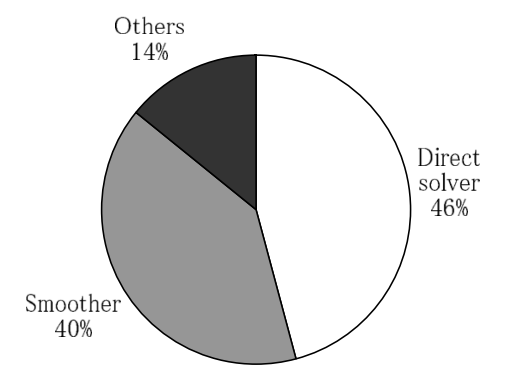

Fig. 8. A breakdown of memory usage.

Table 3. Comparison between MC-NP-BGS and BMC-NP-BGS.

\begin{tabular}{c|c|c}
\hline & MC-NP-BGS & BMC-NP-BGS \\
\hline convergence speed & $\bigcirc$ & $\bigcirc$ \\
\hline parallelism & $\bigcirc$ & $\triangle$ \\
\hline computational time & $\triangle$ & $\bigcirc$ \\
\hline
\end{tabular}

規模 PC クラスタにおいては, 並列度が小さくても計算時 間の短い BMC-NP-BGS が有利となる。

〈5・3・1〉 マルチグリッドソルバの収束性マルチグ リッドソルバが収束するまでに要した反復回数の比較を Table 4 に示す。ただし, 収束の判定は相対残差ノルム：

$$
\frac{\|b-A x\|}{\|b\|}<10^{-6} .
$$

を用いて行った。

スムーザを変えても反復回数はほほ同じ結果となり, ス ムーザによるマルチグリッドソルバの収束性に差は無いと いうことが判った。また, CPU 数を増やしても反復回数に 変化が無いということも確認できた。

$\langle\mathbf{5} \cdot \mathbf{3} \cdot \mathbf{2}\rangle$ スムーザの並列度 並列度は, MC-NP-BGS では各色の節点パッチの個数, BMC-NP-BGS では各色の ブロックの個数と等しくなる。今回のモデルにおいて各久 ムーザの並列度を求めると, Table 5 に示すと抢りになった。 MC-NP-BGS の並列度は約 400 であり，この值は一般的な PC クラスタにとっては十分な大きさと考元られる。一方, BMC-NP-BGS の並列度は 8 となっている。 8 ノード程度 の小規模 PC クラスタであれば問題ないが，それ以上の台 数では効率が低下することが予想される。

マルチグリッドソルバ全体としての並列化効率を考えた 場合，スムーザ以外の処理についてもスムーザと同程度の 並列度が必要とされる。しかし, 特に最も粗なグリッドの
Table 4. Number of iterations.

\begin{tabular}{c|c|c}
\hline smoother & $1 \mathrm{CPU}$ & $5 \mathrm{CPU}$ \\
\hline \hline MC-NP-BGS & 62 & 59 \\
\hline BMC-NP-BGS & 62 & 59 \\
\hline
\end{tabular}

Table 5. Parallelism of the smoothers.

\begin{tabular}{c|c|c}
\hline smoother & number of colors & parallelism \\
\hline \hline MC-NP-BGS & 20 & 408 \\
\hline MC-NP-BGS & 40 & 404 \\
\hline BMC-NP-BGS & 2 & 5 \\
\hline BMC-NP-BGS & 4 & 8 \\
\hline BMC-NP-BGS & 10 & 8 \\
\hline
\end{tabular}

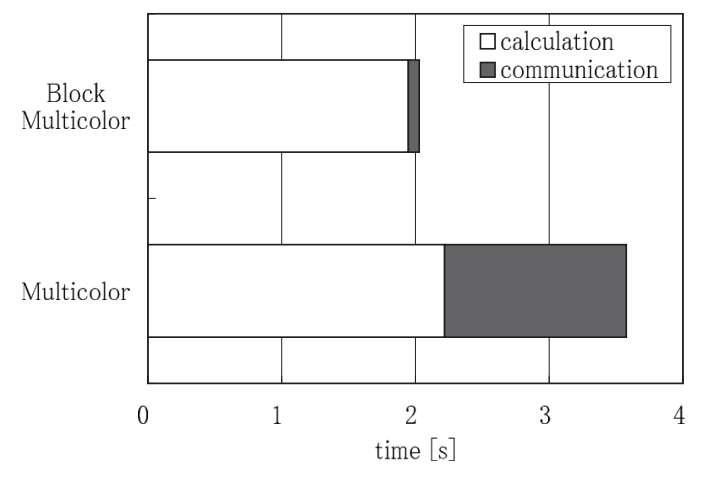

Fig. 9. Computational time of the smoothers.

求解に用いられている直接法ソルバ ( LU 分解と前進後退 代入）は並列化が難しい処理として知られており, 現状で は 8 台程度で頭打ちとなる。よって現時点では, スムーザ としても 8 程度の並列度があればよく, BMC-NP-BGS で も問題ないレべルであると考えられる。ただし，色分け方 法やブロック化方法を工夫することにより，並列度を高め られる可能性が考えられるので, 今後の課題としたい。

$\langle\mathbf{5} \cdot \mathbf{3} \cdot \mathbf{3}\rangle$ スムーザの計算時間＼cjkstart各スムーザの計算時 間を Fig. 9 に示す。これは, マルチグリッドソルバによる反 復計算 1 回中の各グリッドにおけるスムージング計算時間 の合計を表している。ここで, 通信時間は分散メモリ型並 列処理のための PC 間通信と, それに付随する前後処理にか かる時間を表す。これらには, デー夕の送受信, 送受信デー 夕の PACK · UNPACK 処理, 送受信用デー夕配列と送受信 バッファ間のデータ転送に要する時間, 通信関数呼び出し 時のオーバヘッドなどが含まれる。BMC-NP-BGS の計算 時間は, 通信時間, 非通信時間とも, MC-NP-BGS より短い ことが判る。通信時間については, 色数の差による影響と 考えられる。MC-NP-BGS はBMC-NP-BGSよりも色数が 多くなる傾向があり, 今回の数值実験では, BMC-NP-BGS の色数は 2, MC-NP-BGS の色数は 20 であった。多色順 序付け法では色数と同数の通信が必要となるため, 通信の 回数は MC-NP-BGS の方が 10 倍多いことになる。送受信 されるデータの総量はどちらのスムーザも同じなのでデー 夕の送受信時間には差は無いと考えられるが，それ以外の 時間については通信回数によって増加するため, 通信回数 


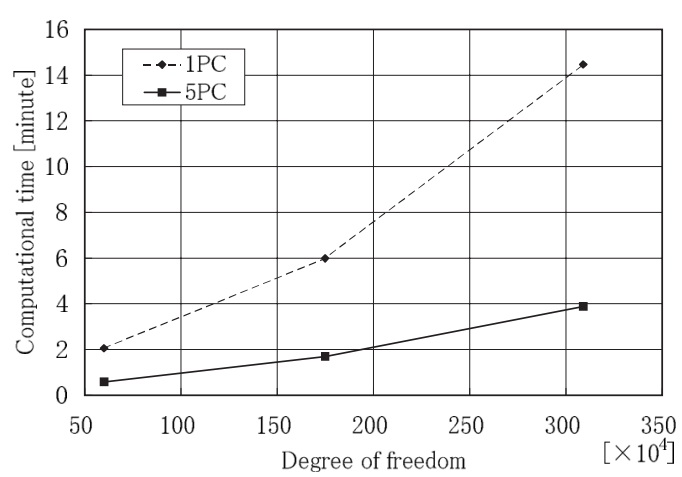

Fig. 10. Computational time of the multigrid solver.

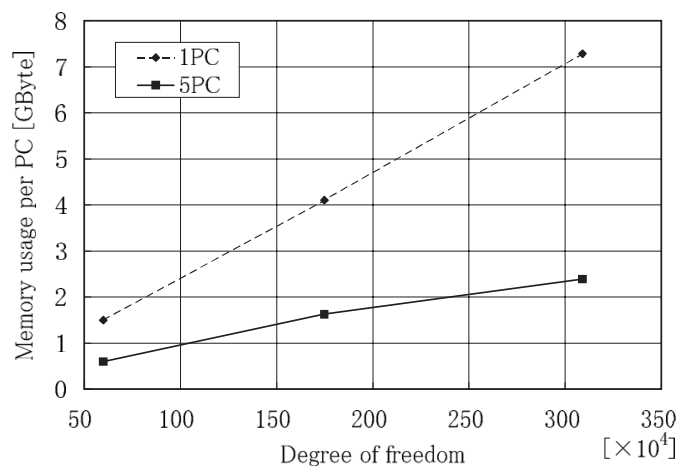

Fig. 11. Memory usage of the multigrid solver.

の少ない BMC-NP-BGS の方が通信時間が短くなる。また 非通信時間については，以下のように説明できる。ブロッ ク化多色順序付け法では同じ色のつけられた節点パッチが 近くにまとまっており，各節点パッチを計算する時に参照 される未知数が，互いに重複している。重複している未知 数についてはキャッシュメモリにあるデータが利用され， メインメモリへの参照回数が少なくなり，計算時間が短く なっている。一方，多色順序付け法では，その上うな重複 を起こさないように色分けを行う必要がある。そのため, ほとんどがメインメモリからの参照となり，計算時間が長 くなる。

〈5・4〉 並列マルチグリッドソルバ全体としての性能

スムーザとして BMC-NP-BGS を使用し，それ以外の処 理についても分散メモリ型並列化した並列マルチグリッド ソルバを作成し性能評価を行った。最も粗なグリッド上で の線形ソルバとしては，並列化された直接法ソルバである MUMPS を導入した。計算時間の測定は，全グリッドの係 数行列と右辺ベクトルが既に与えられている状態から始め, マルチグリッドソルバの反復計算が終了するまでとした。 よってここでの計算時間は，節点パッチの作成・最も粗な グリッドの LU 分解・SQMR 法による反復計算の時間を合 計したものとなる。

PC1 台で計算した場合と PC5 台で計算した場合の，連 立一次方程式の自由度に対する計算時間とメモリ使用量の 関係をそれぞれ Fig. 10 と Fig. 11 に示す。PC5 台で計算し た場合は，並列処理の効果により計算時間が短くなり，メ

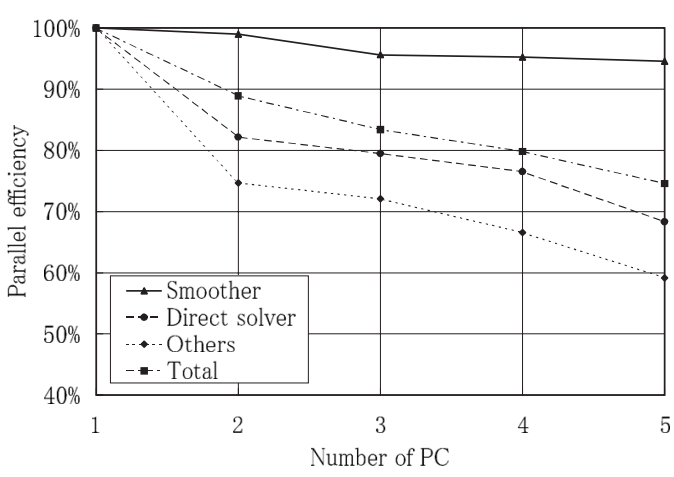

Fig. 12. Parallel efficiency of computational time.

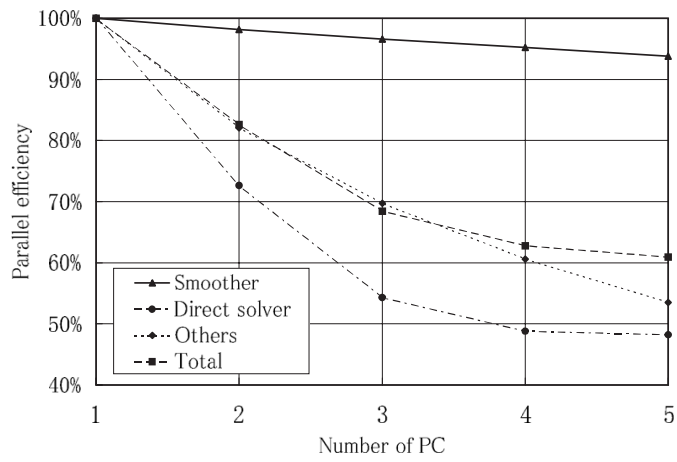

Fig. 13. Parallel efficiency of memory usage.

モリ分散の効果によりメモリ使用量が少なくなっているの が判る。Fig. 11 より，1台あたりのメモリ容量を 2 GByte とした場合, PC1 台では約 80 万自由度までしか計算でき なかったところが，PC5 台では約 240 万自由度まで計算 可能になっていることが判る。 64 bitPC が登場する以前の 32 bitPC では利用できるメモリ容量が 2 GByte に制限され ていたため，80万自由度が限界であった。しかし，従来の 32 bitPC を用いる場合でも PC クラスタを構成し並列マル チグリッドソルバを用いることにより，従来の 3 倍の規模 の解析が可能であることが示された。さらに Fig. 10 より, 計算時間についても，約 300 万自由度の計算において PC 1 台使用時は 14.5 分だったものが PC5 台使用時では 3.9 分 となり, 約 3.7 倍に高速化された。また，標準的な PCによ る PCクラスタ構成は PC1 台に大容量メモリを搭載する構 成と比べて導入コストを大幅に抑えられるという点も，産 業応用の観点からは重要である。

Fig. 12 と Fig. 13 は，それぞれ Fig. 10 と Fig. 11 の結果を 効率の観点から見直したものである。今回提案したBMCNP-BGS スムーザについては PC5 台使用時でも 95 パーセ ントの高効率を維持できていることが確認できる。全体と しては計算時間の効率は 75 パーセント，メモリ使用量の 効率は 61 パーセントとなっている。これは, 直接法ソルバ の LU 分解の効率が低いことによる影響が大きい。今後さ らに効率を上げるためには, 直接法ソルバの効率改善が課 題となる。 


\section{6. まとめ}

$5 \mathrm{CPU}$ の小規模 PC クラスタを対象としてマルチグリッ ド法の分散メモリ型並列化を行い，並列マルチグリッドソ ルバを開発した。同ソルバを用いることにより，計算速度 を 3.7 倍に高速化し，標準的な 32 bitPCでの解析規模を 3.0 倍に増やすことができた。

並列化効率の観点からは，計算コストの大きいスムーザ と直接法ソルバのうちスムーザの並列化に取り組んだ結果, BMC-NP-BGS を用いて PC5 台での並列化効率 95 パーセ ントを達成した。スムーザについて高効率の並列化に成功 したため，直接法ソルバの効率が全体の効率に大きく影響 している状態となり，今後は直接法ソルバの効率を上げて いくことが課題となる。

(平成 18 年 10 月 19 日受付)

\section{文献}

(1) W.L. Briggs, V.E. Henson, and S.F. McCormick: A Multigrid Tutorial Second Edition, SIAM, Philadelphia (2000)

(2) J. Gopalakrishnan, J.E. Pasciak, and L.F. Demkowicz: "Analysis of a multigrid algorithm for time harmonic maxwell equations", SIAM J. Numer. Anal., Vol.42, No.1. pp.90-108 (2004)

(3) M. Mori, K. Yosui, T. Iwashita, E. Kobayashi, and S. Abe: "Preconditioned Iterative Methods for High Frequency Edge Finite Element Electromagnetic Field Analyses", T. IEICE, Vol.J89-C, No.8, pp.521-528 (2006) (in Japanese)

森 倫也·用水邦明 $\cdot$ 岩下武史・小林英一・阿部 眞: 「高周波電磁 界辺要素有限要素解析のための前処理付き反復法」, 信学論 C, J89-C, 8, pp.521-528 (2006-8)

(4) R. Hiptmair: "Multigrid method for maxwell's equations", SIAM J. Numer: Anal., Vol.36, No.1, pp.204-225 (1998)

(5) S. Reitzinger and J. Schoberl: "An algebraic multigrid method for finite element discretizations with edge elements", Numer. Linear Algebra, Vol.9, pp.223-238 (2002)

(6) D.N. Arnold, R.S. Falk, and R. Winther: "Multigird in H(div) and H(curl)", Numer: Math., Vol.85, pp.197-218 (2000)

(7) T. Iwashita and M. Shimasaki: "Algebraic Block Red-Black Ordering Method for Parallelized ICCG Solver With Fast Convergence and Low CommunicationCosts", IEEE Trans. Magnetics, Vol.39-3, pp.1713-716 (2003)

(8) P.R. Amestoy, I.S. Duff, and J.-Y. L'Excellent: "Multifrontal parallel distributed symmetric and unsymmetric solvers", Comput. Methods in Appl. Mech. Eng., Vol.184, pp.501-520 (2000)

(9) P.R. Amestoy, I.S. Duff, J. Koster, and J.-Y. L'Excellent, "A fully asynchronous multifrontal solver using distributed dynamic scheduling", SIAM J. Matrix Analysis \& Applications, Vol.23, No.1, pp.15-41 (2001)

(10) P.R. Amestoy, A. Guermouche, J.-Y. L'Excellent, and S. Pralet: "Hybrid scheduling for the parallel solution of linear systems", Parallel Computing, Vol.32, No.2, pp.136-156 (2006)

(11) N. Obata, T. Mifune, T. Iwashita, and M. Shimasaki: "A Parallel Block Gauss-Seidel Smoother for Algebraic Multigrid Method in Edge-Element Analyses", The Papers of Joint Technical Meeting on tatic Apparatus and Rotating Machinery, IEE Japan, SA-06-68, RM-06-70 (2006) (in Japanese)
小烟信彦·美船 健・岩下武史・島崎眞昭：「辺要素解析に扔ける 代数マルチグリッド法のための並列ブロックガウスザイデルスムー ザ」, 電気学会静止器・回転機合同研資, SA-05-70, RM-06-70 (2006)

(12) R.W. Freund and N.M. Nachtigal: "A new krylov-subspace method for symmetric indefinite linear systems", Proc. of the 14th IMACS World Congress on Computational and Applied Mathematics, pp.1253-1256 (1994)

用 水 邦 明 (非会員) 2003 年早稲田大学大学院理工学研究

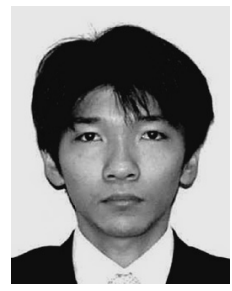
科電気工学専攻修士課程修了。同年 (株) 村田製 作所入社。電磁界解析に関する研究に従事。情報 処理学会会員。

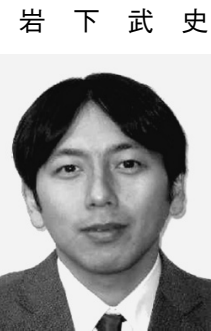

（正員） 1998 年京都大学大学院工学研究科電気 工学専攻博士課程修了。1998 年より京都大学工 学部電気工学科リサーチアソシエイト, 2000 年 より同大学大型計算機センター助手, 2003 年より 同大学学術情報メディアセンター助教授, 現在に 至る。ハイパフォーマンスコンピューティング, 線形反復法, 電磁界解析に関する研究に従事。京 都大学博士 (工学)。IEEE, 情報処理学会, 日本 AEM 学会, 日本計算工学会各会員。

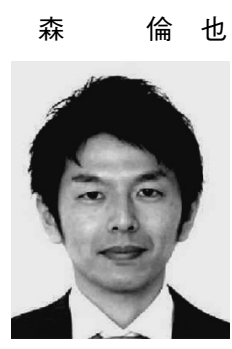

（非会員） 2002 年金沢大学自然科学研究科修士 課程修了。同年 (株) 村田製作所入社。電磁界解 析に関する研究に従事。日本物理学会会員。

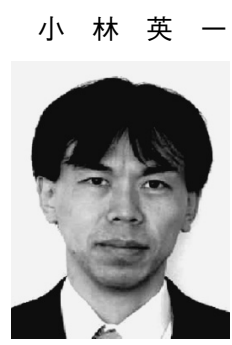

（非会員） 1991 年埼玉大大学院理工学研究科修 士課程修了。同年（株）村田製作所入社。マイク ロ波フィル夕, 電磁界解析に関する研究に従事。 